\title{
Development of low-cost passive sampler from cow bone char for sampling of volatile organic compounds
}

\author{
W. Tala ${ }^{1} \cdot$ S. Chantara ${ }^{1,2} \cdot$ S. Thiansem ${ }^{3} \cdot$ M. Rayanakorn ${ }^{2}$
}

Received: 8 July 2015/Revised: 12 February 2016/ Accepted: 13 April 2016/Published online: 4 May 2016

(C) Islamic Azad University (IAU) 2016

\begin{abstract}
A simple and low-cost passive sampler for collection of volatile organic compounds, specifically benzene, toluene, ethylbenzene and xylene (BTEX), from the ambient air has been developed by using cow bone char (CBC) as an adsorbent with desorption by solvent extraction prior to analysis by gas chromatography-mass spectrometry (GC-MS). The laboratory-made CBC was prepared by calcination process in a partially oxidative atmosphere. The developed passive sampler was tested for a suitable amount of CBC used, diffusion tube type and size, and sampling duration, in a closed chamber saturated with each of the BTEX vapors. With the optimum amount of $250 \mathrm{mg}$ CBC packed in a glass bottle $(82.6 \mathrm{~mm}$ height $\times 11.1 \mathrm{~mm}$ i.d.) and the exposure time of $168 \mathrm{~h}$, detection limits $\left(\mu \mathrm{g} / \mathrm{m}^{3}\right)$ for BTEX determination using this developed sampler together with GC-MS were 0.28 (benzene), 0.79 (toluene), 0.58 (ethylbenzene), 0.28 (p-xylene) and 0.54 (o-xylene). The proposed method was applied to sampling BTEX from selected petrol stations, traffic congestion areas and a rural area in Chiang Mai Province, Thailand. The BTEX concentrations detected were well correlated with their sources as they were the highest at the petrol station sites, lower at the traffic congestion area sites and the lowest at the rural area site. The laboratory-made
\end{abstract}

S. Chantara

somporn.chantara@cmu.ac.th

1 Department of Chemistry and Center of Excellence for Innovation in Chemistry (PERCH-CIC), Faculty of Science, Chiang Mai University, Chiang Mai 50200, Thailand

2 Environmental Science Program, Faculty of Science, Chiang Mai University, Chiang Mai 50200, Thailand

3 Department of Industrial Chemistry, Faculty of Science, Chiang Mai University, Chiang Mai 50200, Thailand passive sampler containing $\mathrm{CBC}$ has thus opened up a possibility of having a simple and effective device for sampling of BTEX in the ambient air.

Keywords Benzene $\cdot$ Ethylbenzene $\cdot$ Gas chromatography-mass spectrometry $\cdot$ Toluene $\cdot$ Xylene

\section{Introduction}

Volatile organic compounds (VOCs) are hazardous compounds, which are contributed to various reactions in the atmosphere, i.e., the formation of photochemical oxidants (Haagen-Smit and Fox 1956; Atkinson 1997; Atkinson et al. 1999; Hoque et al. 2008) associated with smog, secondary organic fine particles and ground-level ozone (Tolnai et al. 2000; Kim 2002; Truc and Oanh 2007). A group of compounds including benzene, toluene, ethylbenzene and xylenes (BTEX) belong to are a particular group of VOCs. They are mainly emitted from road traffic in urban areas, and they could be found up to $60 \%$ of nonmethane VOCs (Lee et al. 2002; Parra et al. 2006) and $35 \%$ of total VOCs (Perry and Gee 1995; FernándezVillarrenaga et al. 2004). Vehicle exhaust is well known to be the main VOCs source in the atmosphere (Fujita et al. 1994; Thijesse et al. 1999; Na 2006; Hoque et al. 2008), especially the emission of BTEX which are probably the most serious effects on air quality (Laowagul et al. 2008). Despite their very low (ppb-ppt) concentrations, BTEX can affect both short and long terms to human health. Benzene, in particular, is classified as a human carcinogen compound group A (USEPA 2012) and a probable human carcinogens class 1 (IARC 2012).

Generally for VOCs adsorption, solid sorbents are often combined with either passive or active samplers. However, 
passive samplers are widely used due to their simple construction, low cost, no electricity requirement (energy saving) and acceptable accuracy (Zabiegała et al. 1999).

There are various types of solid sorbents used for VOCs adsorption such as activated carbon (AC) (Odabasi et al. 2005; Khoder 2007), Anasorb 747 (Seethapathy and Górecki 2010, 2011), Tenax TA (Parra et al. 2008; Hsu and Huang 2009) and Chromosorb106 (Suwanttiga and Limpaseni 2005; Pekey and Yilmaz 2011). These commercial solid sorbents are quite expensive. Therefore, various types of adsorbents for BTX have been introduced; these include semipermeable membrane (Esteve-Turrillas et al. 2007), solid phase membrane (SPM) (Esteve-Turrillas et al. 2009), Tenax TA contained in a screw cap glass bottle for BTX (Thammakhet et al. 2006) and Anasorb $747^{\circledR}$ contained in a permeation passive air sampler for VOCs (Seethapathy and Górecki 2010, 2011).

Bone char is a low-cost adsorbent as it can be obtained directly from carbonization of animal bones. The bone can be collected from various sources such as slaughterhouses, ranchlands, restaurants and markets in general (Akinyi 2013). Kawasaki et al. (2009) reported fluoride adsorption capacities of bone chars produced from different animals, including cattle, pigs, chickens and fishes. They revealed that yielding of bone char from cattle was the highest and it provided higher capacity for fluoride adsorption than bone char from pigs, chickens and fishes. It has been examined as an effective adsorbent for elimination of various pollutants, including decolorizing agent for sugar cane (Girgis et al. 1997), defluoridation from water (Leyva-Ramosa et al. 2010), adsorption of dyes (Ip et al. 2010a, b) and removal of heavy metals in wastewater (Choy and McKay 2005). All these applications of bone char have been attributed to its adsorption taking place in the liquid condition. However, the capability of bone char for gas adsorption has hardly been reported in publication. This work was therefore an attempt to extend the use of a suitable type of bone char, utilizing its adsorption capacity in the condition other than liquid, i.e., in ambient air, with an initial goal of BTEX sampling in various sites in Chiang Mai, the largest city in the northern region of Thailand, where air pollution has been a serious problem each year.

This study was conducted with the aim to produce laboratory-made bone char from cow bones available locally and use it as the adsorbent for sampling of BTEX, a particular group of volatile organic compounds, in ambient air from various sources in the city of Chiang Mai, Thailand. The whole experiment was conducted in 2011-2012. The field experiment alone (sampling of BTEX from ambient air) was carried out in the wet season from July 21-27, 2012.

\section{Materials and methods}

\section{Chemicals}

\section{Preparation of stock standard solutions}

Standard solutions of BTEX (benzene, toluene, ethylbenzene, p-xylene and o-xylene), internal standards (1,4-difluorobenzene and 4-bromofluorobenzene) and surrogate standard (toluene-d8) were supplied by Dr. Ehrenstorfer GmbH (Germany). Methanol was purchased from Merck (Germany). Each solution was prepared in methanol to obtain the concentration of $1000 \mu \mathrm{g} / \mathrm{mL}$ as stock solution. In order to limit losses by evaporation and photooxidation, all solutions were stored in the amber glass-stopped bottles in the freezer compartment of a refrigerator.

\section{Preparation of working standard solutions}

Working standards of BTEX were routinely prepared by accurate dilution from stock standard solutions. Benzene, toluene- $\mathrm{d} 8$ and toluene were prepared in a range of $5.0-60 \mathrm{ng} / \mathrm{mL}$, while ethylbenzene, $\mathrm{p}$-xylene and o-xylene were prepared from 1.0 to $60 \mathrm{ng} / \mathrm{mL}$. A $20 \mu \mathrm{L}$ of $2 \mu \mathrm{g} / \mathrm{mL}$ of internal standards (1,4-difluorobenzene and 4-bromofluorobenzene) was added in all series of solutions.

\section{Materials}

Preparation of laboratory-made cow bone char (LM-CBC)

$L M-C B C$ production Cow bones were crushed to 2-5 mm size and soaked in $5 \%$ of hydrogen peroxide for $24 \mathrm{~h}$ to remove fatty acids and dried at $105{ }^{\circ} \mathrm{C}$ in an oven overnight. They were calcinated under the control temperature set from 500 to $850{ }^{\circ} \mathrm{C}$ in a muffle furnace for $8 \mathrm{~h}$. After that, they were ground into powder and sieved to the 1-2 mm grain size and kept in desiccators at room temperature. The cow bone char powder prepared as such is to be referred to as laboratory-made cow bone char (LM$\mathrm{CBC}$ ) (Fig. 1) in this work.

LM-CBC decontamination The LM-CBC powder had to be cleaned up through a heating process before use. Fifty milligrams portion of LM-CBC was used for each of the testing conditions: (a) non-treated $\mathrm{CBC}$, (b) preheating at $110{ }^{\circ} \mathrm{C}$ for $12 \mathrm{~h}$, (c) preheating at $150{ }^{\circ} \mathrm{C}$ for $3 \mathrm{~h}$, (d) soaking in methanol for $12 \mathrm{~h}$ followed by heating at $150{ }^{\circ} \mathrm{C}$, (e) preheating at $180{ }^{\circ} \mathrm{C}$ for $3 \mathrm{~h}$. The LM-CBC in each condition was then tested for BTEX contaminants by GC-MS. 

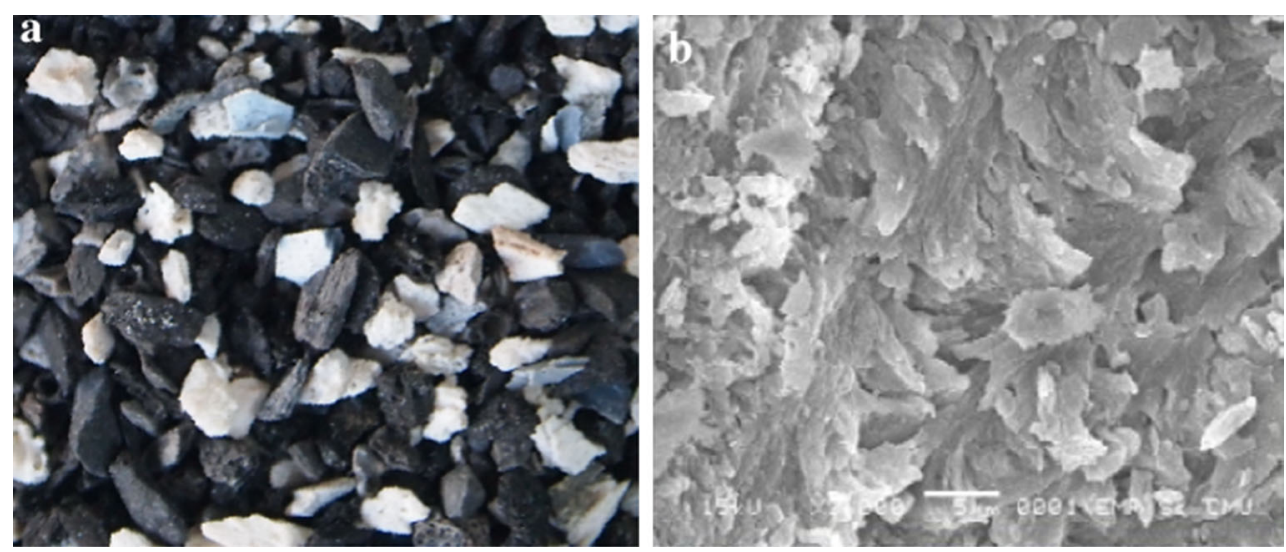

Fig. 1 a Image of LM-CBC, b scanning electron microscope (SEM) of LM-CBC (30,000X)

\section{Gas chromatographic conditions}

Analysis of BTEX was performed using a gas chromatograph (GC-6850, Agilent Technology, USA) combined with a mass selective detector (MSD-5973, Agilent Technology, USA). The injection was done in the splitless mode with HP5-MS capillary column $(30 \mathrm{~m} \times 0.25 \mathrm{~mm}$ i.d., $0.25 \mu \mathrm{m}$ film thickness), using ultra-high pure helium at a constant flow rate of $0.80 \mathrm{~mL} / \mathrm{min}$. The column temperature program was held at $36{ }^{\circ} \mathrm{C}$ for 6 min, increased at $30{ }^{\circ} \mathrm{C} / \mathrm{min}$ to $120^{\circ} \mathrm{C}$, and held at $120^{\circ} \mathrm{C}$ for $5 \mathrm{~min}$. Ionization mode of the mass spectrometer was electron impact (EI) operated at $70 \mathrm{eV}$. The ion source, quadrupole mass analyzer and GC/MSD interface temperatures were 230, 150 and $280{ }^{\circ} \mathrm{C}$, respectively. A mass scanning ranging from 35 to $500 \mathrm{~m} / \mathrm{z}$ was used for full scan acquisitions. The selected masses of the analytes (Table 2) were monitored for quantification and confirmation of each compound.

\section{Quality control of BTEX analysis}

In order to confirm the reliability of BTEX determination by GC-MS, detection limit, precision and linearity were examined when the optimum conditions of GC-MS were obtained. The instrument detection limits (IDLs) of GC-MS for BTEX analysis were obtained by multiplying the standard deviation (SD) of the ten replications by three of the lowest concentrations of the working solutions. The method detection limits (MDLs) were calculated from field blanks (the same kind of sampler that used for sampling, but the bottle was capped all the time during exposure). The values of MDLs were then calculated by multiplying SD values $(n=18)$ by 3 . The precision of this method was calculated from repeatability and reproducibility which was determined by seven repetitive measurements of $15 \mathrm{ng} / \mathrm{mL}$ mixed standard solutions and presented in terms of percent relative standard deviation (\% RSD). The linearity was examined by analysis of solution concentrations from 5 to $2500 \mathrm{ng} / \mathrm{mL}$ (benzene, toluene-d8 and toluene) and 1-2500 ng/mL (ethylbenzene, p-xylene and o-xylene), which were the ranges expected to be found in the ambient air.

\section{Selection of organic solvent for BTEX extraction}

Generally, carbon disulfide $\left(\mathrm{CS}_{2}\right)$ was commonly used as an extraction solvent for VOCs adsorbed by solid sorbents from solid sorbents (Odabasi et al. 2005; Khoder 2007). However, $\mathrm{CS}_{2}$ is highly toxic, flammable and easy to explode (ASTDR 2011). Therefore, methanol was selected as an alternative solvent for extraction of BTEX adsorbed on the surface of the LM-CBC. Its efficiency was investigated by spiking method. Low, medium and high amounts $(6,29$ and $52 \mathrm{ng})$ of mixed BTEX standards and toluene-d8 standard were spiked on $50 \mathrm{mg}$ of the conditioned LMCBC ( $n=5$ for each batch) and incubated at $20-25{ }^{\circ} \mathrm{C}$ for $24 \mathrm{~h}$. Before analysis, each vial was accurately weighed, and weighed again after adding $1.0 \mathrm{~mL}$ of methanol which was used as extraction solvent (ASTM 1988). After that, the solutions were extracted using ultrasonicator for $15 \mathrm{~min}$. Then, each extracted solution was added with 40 $\mu \mathrm{L}$ of $1 \mu \mathrm{g} / \mathrm{mL}$ internal standards (1,4-difluorobenzene and 4-bromofluorobenzene), adjusted to $1 \mathrm{~mL}$ volume and filtered by $0.45 \mu \mathrm{m}$ of nylon syringe filter. The extracted solutions were kept in the refrigerator prior to analysis by GC-MS.

\section{Fabrication of laboratory-made BTEX passive sampler}

To prepare a laboratory-made BTEX passive sampler (LMBTEX-PS), a screw cap glass bottle was packed with an 
appropriate amount of activated LM-CBC. The bottle was then closed with a cap and wrapped with parafilm, and stored in a desiccator at room temperature prior to a sampling. At the sampling site, one set of passive sampler containing five opened and three closed bottles was packed in the protective shelter and then hung at a height between 1.5 and $2.0 \mathrm{~m}$. After the end of the sampling period, it was recapped tightly with a lid and parafilm. It was placed in double layers of the amber ziplock plastic bags for protection from photooxidation before being stored in the refrigerator until analysis.

\section{Method validations}

\section{Adsorption capacity of $L M-C B C$}

In order to obtain an appropriate amount of LM-CBC used in the sampler, five replicates of different amounts of LM-CBC (50, 150 and $250 \mathrm{mg}$ ) were tested. A $50 \mu \mathrm{L}$ of $20 \mu \mathrm{g} / \mathrm{mL}$ of mixed BTEX and toluene-d8 standards were spiked into a petri dish and placed inside a testing chamber. Then, one glass bottle $(0.52 \mathrm{~cm}$ i.d. $\times 3.21 \mathrm{~cm}$ height) containing LM-CBC was placed in the testing chamber. The system was settled at room temperature (about $25-30{ }^{\circ} \mathrm{C}$ ) for $24 \mathrm{~h}$. After that, extraction was carried out and the extracted solution was analyzed for BTEX by GC-MS.

\section{Testing of various sizes of glass bottles for passive sampler}

Different sizes of screw cap glass bottles including type I (32.4 mm height $\times 11.1 \mathrm{~mm}$ i.d.), type II $(41.7 \mathrm{~mm}$ height $\times 10.0 \mathrm{~mm}$ i.d. $)$, type III $(62.8 \mathrm{~mm}$ height $\times 10.5 \mathrm{~mm}$ i.d. $)$ and type IV ( $82.6 \mathrm{~mm}$ height $\times 11.1 \mathrm{~mm}$ i.d.) were tested. Each bottle size was packed with $250 \mathrm{mg}$ of activated LMCBC. One set of an experiment contained three sampling bottles and one blank bottle. Each of them was put in the testing chamber (2.4L). Based on the report from the Pollution Control Department (PCD) of Thailand in 2008 (PCD 2009), the highest concentration of BTEX was about $50 \mu \mathrm{g} / \mathrm{m}^{3}$ at Chiang Mai station. However, concentrations of BTEX from pollution sources such as petrol stations have not been reported. It could be expected that such sources would have higher concentrations of BTEX than the traffic congestion areas. Therefore, two times of the maximum reported concentration were used in this experiment. The $100 \mu \mathrm{g} / \mathrm{m}^{3}$ of mixed BTEX and toluene-d8 standard solution was prepared and diluted. Then, a solution $(100 \mu \mathrm{L}$ of $2.4 \mu \mathrm{g} / \mathrm{mL})$ was spiked into a vial inside the chamber and the chamber lid was immediately closed and wrapped with silicone glue. The system was set up at controlled temperature $\left(20-25{ }^{\circ} \mathrm{C}\right)$ for $24 \mathrm{~h}$. After that, extraction was carried out and the extracted solution was analyzed for BTEX by GC-MS.

\section{Influence of temperature on BTEX adsorption}

One set of the sampler contained three sampling bottles and one blank bottle. Four sets of LM-BTEX-PS were prepared by using two sizes of sampling bottles (type I: $32.4 \mathrm{~mm}$ height $\times 11.1 \mathrm{~mm}$ i.d. and type II: $41.7 \mathrm{~mm}$ height $\times$ $10.0 \mathrm{~mm}$ i.d.). Then, they were simultaneously exposed for $24 \mathrm{~h}$ in the testing chambers containing $100 \mu \mathrm{g} / \mathrm{m}^{3}$ of mixed BTEX and toluene-d8 standards and kept at the room temperatures $\left(27-32{ }^{\circ} \mathrm{C}\right)$ and at the controlled temperatures $\left(20-25^{\circ} \mathrm{C}\right)$ in the air-conditioning room for comparison. After that, they were extracted and analyzed by GC-MS.

\section{Sampling duration of LM-BTEX-PS for BTEX adsorption}

The sampling duration was tested to find out the capacity of the LM-CBC for adsorption of BTEX from air. Thirteen sets of LM-BTEX-PS were exposed in the chamber containing $100 \mu \mathrm{g} / \mathrm{m}^{3}$ of mixed BTEX and toluene-d8 standards. The sampling durations were $8,16,24,32,40,48$, $96,120,168,336,504,672$ and $840 \mathrm{~h}$. This experiment was set up at room temperature in accordance with a real environment.

\section{Use of LM-BTEX-PS in the real environment}

One set of the LM-BTEX-PS (five sampling tubes and three blank tubes fixed in a plastic shelter) was used for sampling of BTEX in ambient air at each sampling site. There were five sampling sites including two traffic congestion areas, two petrol stations and one background site. The samplers were hung at the sampling sites at a height between 1.5 and $2.0 \mathrm{~m}$ above ground level. The sampling was carried out from July 21-27, 2012 (7 days). The air temperature during the sampling was in the range 24.0-28.2 ${ }^{\circ} \mathrm{C}$. After that, they were kept in cooling boxes and transferred back to the laboratory for further analysis.

\section{Results and discussion}

\section{Physical properties of LM-CBC}

The LM-CBC was produced by calcination process using partially oxidative atmosphere by controlling the amount of fuel (liquid petroleum gas) and oxidant (air) ratio to avoid any oxidation on the bone char surface. Due to quite a large-scale production, the calcination temperatures were varied from 500 to $850{ }^{\circ} \mathrm{C}$. In each batch, various colors of CBC (black, gray and white) were observed, but black color was a major appearance. Color changing is generally related to the thermal degradation of the organic matrix (i.e., collagen, protein and fat tissue) of bone char. White 
color indicates the complete degradation of organic matter, whereas dark color indicates the remaining of organic compounds (Ooi et al. 2007). However, the specific surface area is decreased at high-temperature treatment due to an increase in hydroxyapatite crystallite size and loss of elemental carbon (Rojas-Mayorga et al. 2014). According to the literature (Buxbsum 1998; Rojas-Mayorga et al. 2014), when the specific surface area $\left(S_{\mathrm{BET}}\right)$ is increased, the chance of adsorbent-adsorbate interaction is also increasing. This is a positive effect to adsorption process. Many researchers have tried to synthesize bone char under a hypothesis that the experimental parameter of heat treatment plays a significant influence on adsorption property. However, most of the heat treatment optimum condition was that low temperature and black bone char represented the best adsorption property (Mwaniki 1992). The bone char physical properties, i.e., specific surface areas and pore volumes, from various research works are shown in Table 1. The physical properties of LM-CBC from this study could be estimated based on the temperature used in the heat treatment and color appearance.

\section{Removal of contaminants from LM-CBC}

Use of the LM-CBC for BTEX sorbent in the air passive sampler was started from the cleanup step of the CBC by various conditions. Bone char is produced by carbonization of cow bone, and it contains about $10 \%$ carbon and $90 \%$ hydroxyapatite. Its application as air pollutant adsorbent was reported only for formaldehyde but without decontamination. Kaseva (2006) varied the temperature $\left(100-800{ }^{\circ} \mathrm{C}\right.$ ) for bone char regeneration by using the heating method. The recommended temperature limits used for the commercial solid sorbents are $190{ }^{\circ} \mathrm{C}$ (XAD2), $250{ }^{\circ} \mathrm{C}$ (Anasorb 727), $350{ }^{\circ} \mathrm{C}$ (Anasorb 727 and Tenax TA and $250-275^{\circ} \mathrm{C}$ (Chromosorb). In this work, low temperatures were used because the reaction between BTEX compounds and bone char is physical adsorption and their interaction is quite weak. In addition, using low temperatures could protect changes of bone char characteristic and save cost from using high energy. Temperatures applied for decontamination were 110,150 and $180{ }^{\circ} \mathrm{C}$. After the treatment, low concentration of BTEX $(71 \mathrm{ng} / \mathrm{g})$

Table 1 Summary of some physical properties of bone char from some research studies

\begin{tabular}{|c|c|c|c|c|c|c|c|c|}
\hline \multirow[t]{2}{*}{ Raw material } & \multicolumn{2}{|l|}{ Thermal treatment } & \multicolumn{3}{|c|}{$\begin{array}{l}\text { Textural parameters } \\
\text { of bone char }\end{array}$} & \multirow[t]{2}{*}{ Color } & \multirow[t]{2}{*}{ Application } & \multirow[t]{2}{*}{ References } \\
\hline & Temperature $\left({ }^{\circ} \mathrm{C}\right)$ & Condition & $\begin{array}{l}S_{\mathrm{BET}} \\
\left(\mathrm{m}^{2} / \mathrm{g}\right)\end{array}$ & $\begin{array}{l}V_{\text {Total }} \\
\left(\mathrm{cm}^{3} / \mathrm{g}\right)\end{array}$ & $\begin{array}{l}\text { Pore size } \\
(\mathrm{nm})\end{array}$ & & & \\
\hline Bovine bone & $\begin{array}{l}350 \\
450 \\
600\end{array}$ & Heat treatment & - & - & - & $\begin{array}{l}\text { Black } \\
\text { Gray } \\
\text { White }\end{array}$ & $\begin{array}{l}\text { Removal of } \\
\text { fluoride in } \\
\text { water }\end{array}$ & Mwaniki (1992) \\
\hline $\begin{array}{l}\text { Cow femur } \\
\text { bone }\end{array}$ & $\begin{array}{l}400 \\
600 \\
800 \\
1000\end{array}$ & $\begin{array}{l}\text { Annealing under } \\
\text { ambient condition }\end{array}$ & $\begin{array}{l}85 \\
71.7 \\
7 \\
2.4\end{array}$ & $\begin{array}{l}- \\
- \\
- \\
-\end{array}$ & $\begin{array}{l}- \\
- \\
- \\
-\end{array}$ & $\begin{array}{l}- \\
- \\
- \\
-\end{array}$ & $\begin{array}{l}\text { Removal of } \\
\text { cobalt in water }\end{array}$ & $\begin{array}{l}\text { Dimović et al. } \\
\text { (2009) }\end{array}$ \\
\hline $\begin{array}{l}\text { Cattle and } \\
\text { sheep bone }\end{array}$ & 450 & $\begin{array}{l}\text { Pyrolysis in a } \\
\text { rectangular } \\
\text { furnace }\end{array}$ & 105.24 & 0.367 & 13.95 & - & $\begin{array}{l}\text { Removal of } \\
\text { formaldehyde } \\
\text { in air }\end{array}$ & $\begin{array}{l}\text { Rezaee et al. } \\
\text { (2013) }\end{array}$ \\
\hline $\begin{array}{l}\text { Cow femur } \\
\text { bone }\end{array}$ & $\begin{array}{l}650 \\
700 \\
800\end{array}$ & $\begin{array}{l}\text { Pyrolysis in an inert } \\
\text { atmosphere }\left(\mathrm{N}_{2}\right. \\
400 \mathrm{ml} / \mathrm{min})\end{array}$ & $\begin{array}{l}118 \\
110 \\
96\end{array}$ & $\begin{array}{l}0.24 \\
0.233 \\
0.224\end{array}$ & $\begin{array}{l}8.13 \\
8.47 \\
9.33\end{array}$ & $\begin{array}{l}- \\
- \\
-\end{array}$ & $\begin{array}{l}\text { Removal of } \\
\text { fluoride in } \\
\text { water }\end{array}$ & $\begin{array}{l}\text { Rojas-Mayorga } \\
\text { et al. (2013) }\end{array}$ \\
\hline $\begin{array}{l}\text { Cow femur } \\
\text { bone }\end{array}$ & $\begin{array}{l}650 \\
700 \\
800 \\
900 \\
1000\end{array}$ & $\begin{array}{l}\text { Carbonization using } \\
\text { a partially } \\
\text { oxidative } \\
\text { atmosphere }\left(\mathrm{CO}_{2}\right. \\
400 \mathrm{ml} / \mathrm{min})\end{array}$ & $\begin{array}{l}62 \\
69 \\
9 \\
4 \\
2\end{array}$ & $\begin{array}{l}0.2 \\
0.23 \\
0.16 \\
0.04 \\
0.02\end{array}$ & $\begin{array}{l}- \\
- \\
- \\
- \\
-\end{array}$ & $\begin{array}{l}\text { Black } \\
\text { Black } \\
\text { Gray } \\
\text { White } \\
\text { White }\end{array}$ & $\begin{array}{l}\text { Removal of } \\
\text { fluoride in } \\
\text { water }\end{array}$ & $\begin{array}{l}\text { Rojas-Mayorga } \\
\text { et al. (2014) }\end{array}$ \\
\hline $\begin{array}{l}\text { Cow bone } \\
\text { (laboratory- } \\
\text { made) }\end{array}$ & $500-850$ & $\begin{array}{l}\text { Calcination using a } \\
\text { partially oxidative } \\
\text { atmosphere }\end{array}$ & - & - & - & $\begin{array}{l}\text { Mostly } \\
\text { black (a } \\
\text { bit of } \\
\text { gray and } \\
\text { white } \\
\text { mixture) }\end{array}$ & $\begin{array}{l}\text { Used as } \\
\text { absorbent for } \\
\text { sampling of } \\
\text { BTEX from } \\
\text { ambient air }\end{array}$ & This study \\
\hline
\end{tabular}

$S_{B E T}$ specific surface areas, $V_{\text {Total }}$ total pore volume 
was still detected as contaminant in the LM-CBC. Therefore, the detected value was subtracted from the BTEX concentrations detected in the samples in every routine experiment.

\section{Analytical feature of the method}

Chromatogram of BTEX and toluene-d8 analyzed by GCMS in this experiment is shown in Fig. 2. All peaks were completely separated from each other, and the analysis time was about $9 \mathrm{~min}$. The detection limit, precision and linearity of the GC-MS for BTEX analysis are shown in Table 2.

The values of the instrument detection limits (IDLs) of GC-MS for BTEX analysis ranged from 0.38 to $1.44 \mathrm{ng} /$ $\mathrm{mL}$, while the values of the method detection limits (MDLs) of the laboratory-made BTEX passive sampler (LM-BTEX-PS) ranged from 0.28 to $0.79 \mu \mathrm{g} / \mathrm{m}^{3}$.

The precision of the analysis of BTEX and toluene-d8 was assessed from repeatability and reproducibility. Relatively high precision was obtained (1.8-7.3\%RSD for repeatability and 3.1-13\%RSD for reproducibility).

GC-MS presented excellent linearity for all of the analytes (Table 2) with the coefficient of determination higher than 0.995 for BTEX in the concentration range $1-2500 \mathrm{ng} / \mathrm{mL}$

\section{Efficiency of methanol for BTEX extraction}

Use of methanol for BTEX extraction provided relatively good percent recoveries for all ranges of the spiked concentrations (low, medium and high). Their recoveries were 71-86\% (benzene), 74-89\% (toluene-d8), 64-70\% (toluene), 84-110\% (ethylbenzene), 73-92\% (p-xylene) and $82-104 \%$ (o-xylene). These results indicated that intermolecular force between LM-CBC with BTEX and toluene-d8 was quite weak (van der Waal force). It can be revealed that methanol is an optional solvent, which provided high efficiency of BTEX extraction.

\section{Validation of LM-BTEX-PS}

\section{Adsorption efficiency of $L M-C B C$}

The amount of LM-CBC packed in the diffusion bottle should be suitable with the quantity of BTEX in the ambient air. Figure 3 shows the concentration of BTEX adsorbed on different LM-CBC in terms of percent recoveries.

It was found that BTEX concentrations found in each condition with various amounts of LM-CBC $(n=5)$ packed were not significantly different $(p>0.05)$. Thus, a $50 \mathrm{mg}$ quantity of LM-CBC was selected for BTEX adsorption from ambient air in this experiment. However, recoveries of the BTEX were still low, possibly due to inappropriate size of diffusion bottles, low amount of LMCBC used and too short sampling time. To confirm the adsorption efficiency based on the availability of diffusion bottle and Fick's law (Górecki and Namiesnik 2002; Seethapathy et al. 2008), size of diffusion bottle was optimized for better recoveries of the analytes. The amount of LM-CBC used was also increased from 50 to $250 \mathrm{mg}$.

\section{Comparison of diffusion bottles}

Four sizes of diffusion bottles (types I, II, III and IV) were examined $(n=3)$ to be used as a passive sampler for BTEX. In each bottle, $250 \mathrm{mg}$ of LM-CBC was packed. It was found that the recoveries of all analytes sampling by the diffusion bottle types III and IV were obviously higher than types I and II (Fig. 4). Between types III and IV, it was found that recoveries obtained from type IV were slightly better than type III. Type IV was therefore chosen for the further experiment. However, it was found that percent recoveries of benzene (15.4\%), toluene-d8 (32.0\%),

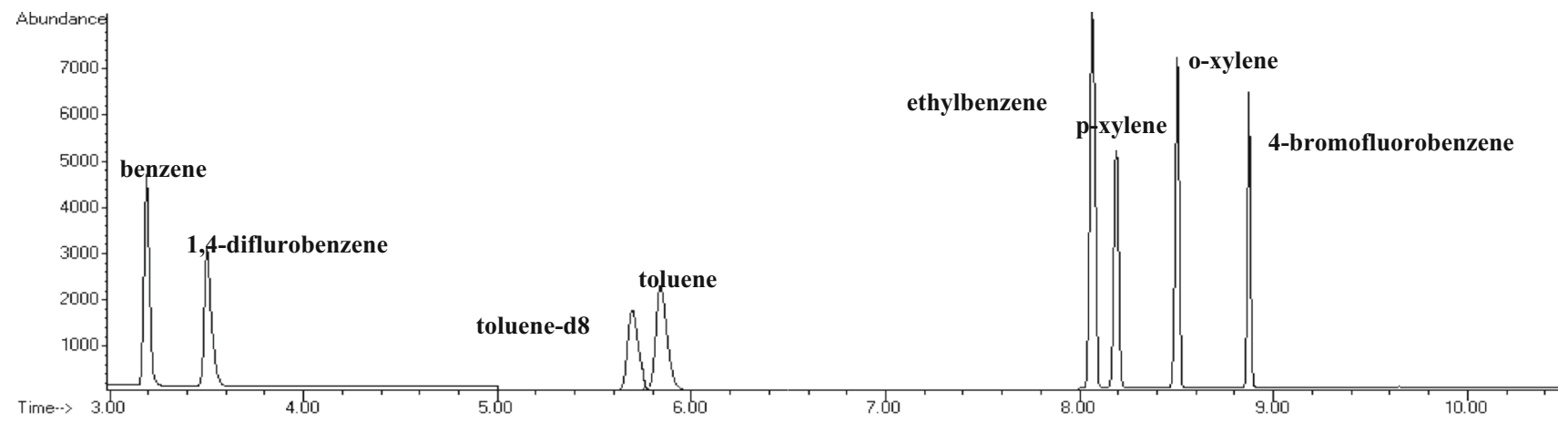

Fig. 2 Chromatogram of $1 \mu \mathrm{g} / \mathrm{mL}$ BTEX standards and toluene-d8 standard in SIM mode 
Table 2 Analytical characteristics of BTEX analyzed by GC-MS

\begin{tabular}{|c|c|c|c|c|c|c|c|c|}
\hline Compound & $\begin{array}{l}\text { Retention } \\
\text { time (min) }\end{array}$ & $\begin{array}{l}\text { Confirm ion } \\
(\mathrm{m} / \mathrm{z})\end{array}$ & Linearity & $R^{2}$ & $\begin{array}{l}\text { IDL } \\
(\mathrm{ng} / \mathrm{mL})\end{array}$ & $\begin{array}{l}\text { MDL } \\
\left(\mu \mathrm{g} / \mathrm{m}^{3}\right)\end{array}$ & $\begin{array}{l}\text { Repeatability } \\
\% \text { RSD }\end{array}$ & $\begin{array}{l}\text { Reproducibility } \\
\% \text { RSD }\end{array}$ \\
\hline Benzene & 3.156 & 78 & $5-2500$ & 0.9984 & 0.82 & 0.28 & 3.7 & 6.9 \\
\hline 1,4-difluorobenzene ${ }^{*}$ & 3.470 & 114 & - & - & - & - & - & - \\
\hline Toluene-d $8^{* *}$ & 5.707 & 98 & $5-2500$ & 1.0000 & 1.05 & $-{ }^{\mathrm{a}}$ & 4.0 & 12 \\
\hline Toluene & 5.854 & 91 & $5-2500$ & 0.9996 & 1.44 & 0.79 & 7.3 & 13 \\
\hline Ethylbenzene & 8.067 & 91,106 & $1-2500$ & 0.9993 & 0.46 & 0.58 & 1.8 & 3.1 \\
\hline$p$-Xylene & 8.189 & 91,106 & $1-2500$ & 0.9998 & 0.49 & 0.28 & 2.4 & 5.8 \\
\hline$o$-Xylene & 8.506 & 91,106 & $1-2500$ & 0.9995 & 0.38 & 0.54 & 3.5 & 8.7 \\
\hline 4-Bromofluorobenzene & 8.875 & 95,174 & - & - & - & - & - & - \\
\hline
\end{tabular}

${ }^{\text {a }}$ It is not found in the real sample

* Internal standard and ** surrogated standard

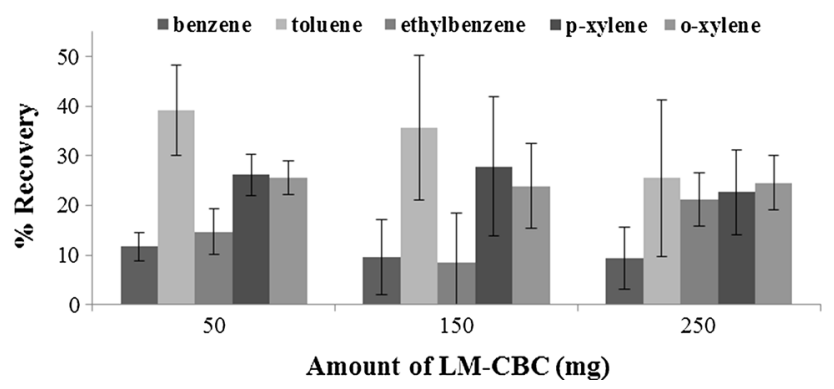

Fig. 3 Percent recoveries of BTEX from different amounts of LMCBC used

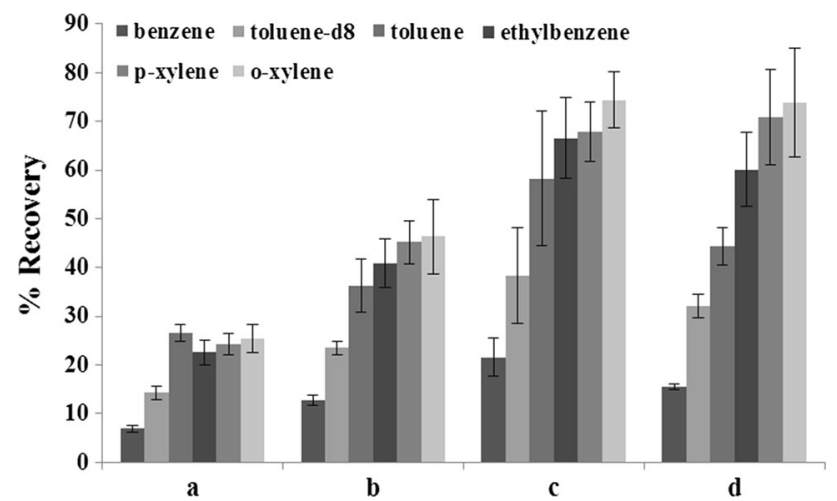

Fig. 4 Percent recoveries of BTEX on the different type of diffusion tubes: a type I, $\mathbf{b}$ type II, $\mathbf{c}$ type III and $\mathbf{d}$ type IV

toluene $(44.3 \%)$, ethylbenzene $(60.1 \%)$ were lower than $70 \%$. The results were the same for all testing conditions. It is probably because the adsorption process is based on the nature of the adsorbent (LM-CBC) and adsorbate (BTEX and toluene-d8). The chemical properties of adsorbate, i.e., polarity, molecular weight, boiling point, vapor pressure and $\log \mathrm{K}_{\mathrm{OW}}$ (Table 3), are elemental factors in the interaction between the different BTEX and toluene-d8 for the active sites on the LM-CBC. On the other hand, the adsorption can rely on the number and type of substitute group on benzene ring. They play an important role with steric hindered groups (i.e., $-\mathrm{CH}_{3}$ or $-\mathrm{CH}_{2} \mathrm{CH}_{3}$ ) which contribute to increase the distance between the plane of the ring and surface of the adsorbent (Daifullah and Girgis 2003) and also protect different type of compounds to interact with active sites within the deepest of adsorbent (micropore). Therefore, the compounds have more chance to be adsorbed on the active site by non-specific attraction (van der Waal force). The CBC contains about $10 \%$ elementary carbon and $90 \%$ hydroxyapatite (Medellin-Castillo et al. 2014). The inorganic part presents the ability to adsorb ions, while the organic part presents the ability to nonpolar organic compounds (RojasMayorga et al. 2014). The activated carbon has been reported to possess high affinity to adsorb BTEX compounds (Daifullah and Girgis 2003). Relatively high molecular compounds (i.e., BTEX and toluene-d8) could thus pass easily through the pore and physically adsorb on the active site of LM-CBC.

\section{Temperature dependency of BTEX adsorption}

Percent recoveries of all compounds obtained from the controlled temperature $\left(20-25^{\circ} \mathrm{C}\right)$ were $2-13$ times higher than those in the un-controlled temperature $\left(27-32^{\circ} \mathrm{C}\right)$ for both two types of diffusion bottles (Fig. 5). Increase in 
Table 3 Selected physical and chemical properties associated with BTEX and toluene-d8 Sources Esteve-Turrillas et al. (2007), Rowe et al. (2005)

\begin{tabular}{lllcccc}
\hline Compound & Log $\mathrm{K}_{\mathrm{OW}}$ & $\begin{array}{l}\text { Boiling } \\
\text { point }\left({ }^{\circ} \mathrm{C}\right)\end{array}$ & $\begin{array}{l}\text { Vapor pressure } \\
\left.\text { (torr at } 25{ }^{\circ} \mathrm{C}\right)\end{array}$ & $\begin{array}{l}\text { Molecular } \\
\text { weight }(\mathrm{g} / \mathrm{mol})\end{array}$ & $\begin{array}{l}\text { Diffusion } \\
\text { coefficient } \\
\text { in air }\left(\mathrm{m}^{2} / \mathrm{s}\right)\end{array}$ \\
\hline Benzene & 2.15 & 80.1 & 100.84 & $\begin{array}{l}\text { Henry's law } \\
\text { constant } \\
\left(\mathrm{kPa} \mathrm{m}^{3} / \mathrm{mol}\right)\end{array}$ \\
Toluene & 2.69 & 110.6 & 28.47 & 78.11 & 0.93 & 0.55 \\
Ethylbenzene & 3.15 & 136.3 & 9.51 & 92.14 & 0.84 & 0.67 \\
m-Xylene & 3.20 & 139.3 & 8.29 & 106.17 & 0.75 & 0.68 \\
p-Xylene & 3.15 & 137.5 & 8.75 & 106.17 & 0.67 & $0.50-0.78$ \\
o-Xylene & 2.77 & 144.0 & 6.62 & 106.17 & 0.73 & $0.51-0.88$ \\
Toluene-d8* & 2.73 & 110.0 & 27.70 & 100.18 & - & 0.50 \\
\hline
\end{tabular}

* http://www.guidechem.com/reference/dic-9768.html

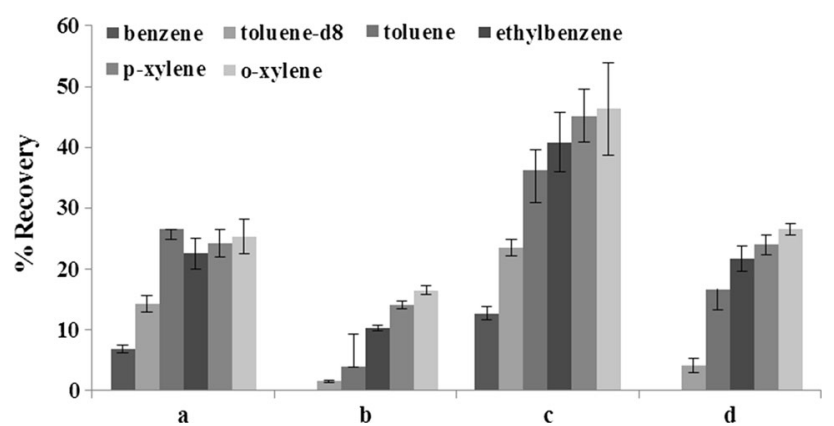

Fig. 5 Percent recoveries of BTEX from different conditions: a type I controlled temperature, b type I ambient temperature, c type II controlled temperature, $\mathbf{d}$ type II ambient temperature

temperature can basically be explained by the hypothesis that the process of gas-solid adsorption is a physical adsorption and an exothermic reaction (Attard and Barnes 2008). The BTEX and toluene-d8 molecules are attracted with weak intermolecular force (van der Waals force) toward the LM-CBC, and they have low enthalpy value (less than $30 \mathrm{~kJ} / \mathrm{mol}$ ) (Kolasinski 2008). Reversing the adsorption process (desorption process) without high activation energy could be facile in this case, and an exothermic process could occur when the temperature was increased. The system was adjusted to remove the amount of heat in the system for restoring the heat of reaction by presenting the endothermic reaction which is reversely an exothermic reaction according to the Le Chatelier's principle. Therefore, the amount of LM-CBC combined with BTEX compounds was reduced.

$\mathrm{M}_{(\mathrm{g})}+\mathrm{S}_{\text {(surface site) }} \underset{k_{d}}{\stackrel{K_{a}}{\rightleftarrows}} \mathrm{M}-\mathrm{S}_{\text {(Associative adsorption) }}$

where $\mathrm{M}_{(\mathrm{g})}, \mathrm{S}_{\text {(surface site), }}, \mathrm{M}-\mathrm{S}_{\text {(Associative adsorption), }}, k_{\mathrm{a}}$ and $k_{\mathrm{d}}$ are molecule of gas, solid sorbent, molecule of gaseous com-

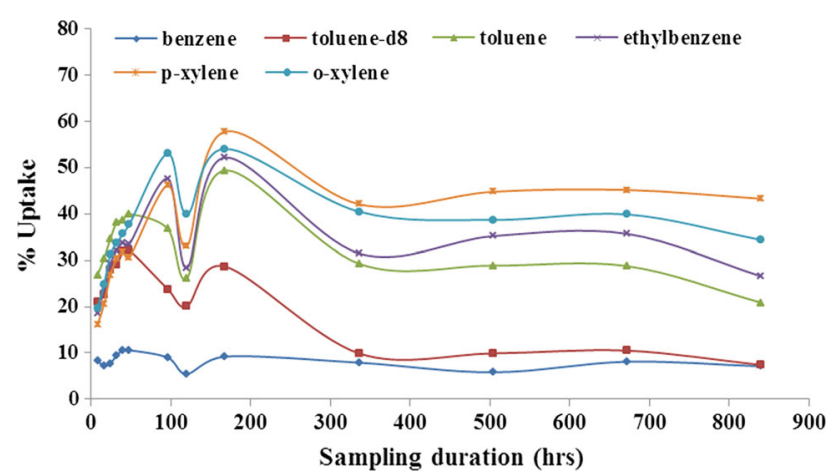

Fig. 6 Capacities of LM-CBC on BTEX and toluene-d8 adsorption

bined with solid sorbent, rate constants for the adsorption and desorption, respectively (Attard and Barnes 2008).

Moreover, increasing temperature has influenced the diffusion coefficient of a compound in the air (D) and pressure (P) (Pennequin-Cardinal et al. 2005) as follows:

$D \alpha \frac{T^{\frac{3}{2}}}{p}$

When the temperature rises up for $1{ }^{\circ} \mathrm{C}$, the diffusion rate of each compound is slightly increased about $0.5 \%$. Therefore, BTEX and toluene-d8, which are normally present in a gaseous phase at room temperature, preferred to distribute in the air more than being adsorbed on the adsorbent.

Influence of sampling duration on the operation of LMBTEX-PS

Sampling duration was tested in order to obtain the maximum adsorption of BTEX compound by GC-MS. The results in Fig. 6 showed that all of analytes (toluene-d8, toluene, ethylbenzene, p-xylene and 
Table 4 Mean concentrations (SD) of BTEX obtained from different sampling sites by LMBTEX-PS

\begin{tabular}{llllll}
\hline Compound & \multicolumn{4}{l}{ Concentration $\left(\mu \mathrm{g} / \mathrm{m}^{3}\right)$} \\
\cline { 2 - 6 } & Benzene & Toluene & Ethylbenzene & p-Xylene & o-Xylene \\
\hline Petrol station 1 $(n=5)$ & $0.80(0.15)$ & $9.33(0.68)$ & $1.00(0.22)$ & $10.7(0.74)$ & $4.21(0.40)$ \\
Petrol station 2 $(n=5)$ & $1.97(2.09)$ & $5.51(0.47)$ & $0.68(0.14)$ & $7.22(0.60)$ & $2.75(0.28)$ \\
Traffic congestion 1 $(n=5)$ & $0.94(0.56)$ & $0.86(0.13)$ & N.D. & $0.94(0.29)$ & $0.44(0.09)$ \\
Traffic congestion 2 $(n=5)$ & $1.04(0.74)$ & N.D. & N.D. & N.D. & N.D. \\
Background site $(n=5)$ & N.D. & N.D. & N.D. & N.D. & N.D. \\
\hline
\end{tabular}

N.D. not detected o-xylene) were adsorbed rapidly within $72 \mathrm{~h}$, which indicated high adsorption rates of the LM-CBC for BTEX in this period. The maximum adsorption was obtained at $168 \mathrm{~h}$, where adsorption capacity of the LMCBC was reached. After that, the uptake rate was reduced. The uptake rate of benzene by the LM-CBC was low, which is probably because it has high vapor pressure and low $\log \mathrm{K}_{\mathrm{OW}}$ (Table 3) which indicated that it prefers to distribute in the gaseous phase more than being adsorbed on LM-CBC. The optimum sampling duration in this work was $168 \mathrm{~h}$ as the highest amounts of BTEX were obtained from this sampling duration

\section{Use of the developed passive samplers for real sampling}

Five selected sampling sites in Chiang Mai Province, Thailand, were two petrol stations, two traffic congestion areas, which are expected to be major BTEX emission sources, and one background site in the rural area. One set of the LM-CBC-PS was set up at each sampling site. The BTEX concentrations (Table 4) detected at both petrol stations in descending order were p-xylene $>$ toluene $>0$ xylene $>$ ethylbenzene $>$ benzene (except at the petrol station 2, where concentration of benzene was slightly higher than ethylbenzene). The difference in order might be due to type and quantity of fuel sale in each petrol station. The concentrations of benzene, toluene, ethylbenzene, $\mathrm{p}$-xylene and o-xylene detected at the petrol station 1 were $0.80,9.33,1.00,10.7$ and $4.21 \mu \mathrm{g} / \mathrm{m}^{3}$, whereas they were $1.97,5.51,0.68,7.22$ and $2.75 \mu \mathrm{g} / \mathrm{m}^{3}$ at petrol station 2 . The concentrations were significantly different between the petrol stations $(p>0.05)$, which was due to different fuel loads at the two petrol stations. The petrol station 1 was reported to have a higher fuel load than the petrol station 2 (Sopajaree et al. 2011); therefore, the BTEX values (except benzene) measured at both stations were well reflected their fuel loads.
In the traffic congestion area 1, the compound concentrations in descending order were benzene $\sim$ p-xylene $\left(0.94 \mu \mathrm{g} / \mathrm{m}^{3}\right)>$ toluene $\left(0.86 \mu \mathrm{g} / \mathrm{m}^{3}\right)>$ o-xylene $(0.44 \mu \mathrm{g} /$ $\left.\mathrm{m}^{3}\right)$, whereas only benzene $\left(1.04 \mu \mathrm{g} / \mathrm{m}^{3}\right)$ was detected in the traffic congestion area 2. Regarding the above air pollutants detected in the traffic congestion areas of Chiang Mai, it is worth discussing this study in comparison with the earlier work conducted by the Pollution Control Department (PCD) of Thailand, which collected samples in 2008 at the air quality monitoring station (about $2 \mathrm{~km}$ from the study sites in this work). The air sampling had been done using a canister for $24 \mathrm{~h}$, once a month for a whole year and transported for analysis by GC-MS in Bangkok. The reported annual concentrations (min-max) were $1.3-6.6 \mu \mathrm{g} / \mathrm{m}^{3}$ (benzene), $8.1-46 \mu \mathrm{g} / \mathrm{m}^{3}$ (toluene), $0.58-11.0 \mu \mathrm{g} / \mathrm{m}^{3}$ (ethylbenzene), $0.47-0.53 \mu \mathrm{g} /$ $\mathrm{m}^{3}$ (p-xylene) and 0.67-5.9 $\mu \mathrm{g} / \mathrm{m}^{3}$ (o-xylene) (PCD 2009). In this study, concentrations of BTEX compounds were obviously lower than those reported by the PCD. Such discrepancies were possibly attributed by meteorological factors during the sampling period (July 21-27, 2012), when it rained almost every day $(0.6-42.2 \mathrm{~mm})$ with $75-95 \%$ relative humidity and $24.0-28.2{ }^{\circ} \mathrm{C}$ temperature (Thailand Meteorological Department 2012). These factors could reduce air pollutant levels by the washout effect.

Concentrations of BTEX at the traffic congestion area 2 (23,697 vehicles/day) were higher than those at the area 1 (34,265 vehicles/day). The BTEX concentrations were well related to the traffic volume recorded. None of the BTEX was detected at the background site. It can be concluded that the LM-CBC passive sampler performed well in collecting volatile organic compounds from ambient air.

Based on the results, LM-BTEX-PS can be used for sampling of BTEX from ambient air, in which the LMCBC was used as solid sorbent. The BTEX concentrations in this work were higher in petrol stations than in traffic congestion areas. No similar pattern of BTEX was found 
between three groups of sampling sites. These could be described on the association of type of fuel, age and speed of vehicle, design of engine, fuel control, combustion condition, driving mode, refueling time and evaporation process (Brocco et al. 1997; Na et al. 2004) as well as the basis of meteorological conditions, including temperature and wind velocity (Esteve-Turrillas et al. 2007; Seethapathy et al. 2008).

\section{Conclusion}

The combined method of using LM-BTEX passive sampler, solvent extraction and analysis by GC-MS can be effectively used for determination of BTEX in ambient air. The results obtained from various sampling sites including the petrol stations, traffic congestion areas and background site were clearly classified. This sampling method was simple, easy to use and effective. Therefore, the cost of BTEX determination for air quality assessment can be reduced through the cost of the sampler. The LM-BTEX-PS developed in this study to be used as an air passive sampler although yielded low recoveries of BTEX adsorption on LM-CBC, the study as a whole could still be mentioned as a pioneering work with regard to the use of $\mathrm{CBC}$ for air pollution monitoring purposes. Future work in line with this study should further modify the active sites of $\mathrm{CBC}$ for specific adsorption of BTEX in order to improve sampling efficiency.

Acknowledgments Financial support from the Center of Excellence for Innovation in Chemistry (PERCH-CIC) and Graduate School of Chiang Mai University is gratefully acknowledged.

\section{References}

Akinyi (2013) Determination of the extent to which the bucket fluoride fukters supplied by the catholic diocese of nakuru are able to remove excessive fluoride from drinking water in nakuru town, Kenya. Int J Adv Res Chem Sci 1(10):392-399

ASTDR (2011) Medical Management Guidelines for Carbon Disulfide. http://www.atsdr.cdc.gov $/ \mathrm{mmg} / \mathrm{mmg}$.asp?id=470\&tid=84

ASTM (1988) Method D 3687-84: standard practice for analysis of organic compound vapors collected by the activated charcoal tube adsorption method. J ASTM Int, Pennsylvania

Atkinson R (1997) Gas-phase tropospheric chemistry of volatile organic compounds 1 Alkanes and alkenes. J Phys Chem Ref Data 26:215-290
Atkinson R, Baulch DL, Cox RA, Hampson RFJ, Kerr JA, Rossi MJ, Troe J (1999) Evaluated kinetic and photochemical data for atmospheric chemistry, Organic species Supplement VII. J Phys Chem Ref Data 28(2):391-393

Attard G, Barnes C (2008) Surfaces. Oxford University Press, Oxford

Brocco D, Fratarcangeli R, Lepore L, Petricca M, Ventrone I (1997) Determination of aromatic hydrocarbons in urban air of Rome. Atmos Environ 31(4):557-566

Buxbsum G (1998) Industrial inorganic pigment. Wiley-VCH, Federal Republic of Germany

Choy KKH, Mckay G (2005) Sorption of cadmium, copper, and zinc ions onto bone char using Crank diffusion model. Chemosphere 60(8):1141-1150

Daifullah AAM, Girgis BS (2003) Impact of surface characteristics of activated carbon on adsorption of BTEX. Colloids Surf A: Physicochem Eng Aspects 214(1-3):181-193

Dimović S, Smičiklas I, Plećaš I, Antonović D, Mitrić M (2009) Comparative study of differently treated animal bones for $\mathrm{Co}^{2+}$ removal. J Hazard Mater 164(1):279-287

Esteve-Turrillas FA, Pastor A, De La Guardia M (2007) Assessing air quality inside vehicles and at filling stations by monitoring benzene, toluene, ethylbenzene and xylenes with the use of semipermeable devices. Anal Chim Acta 593(1):108-116

Esteve-Turrillas FA, Ly-Verdú S, Pastor A, De La Guardia M (2009) Development of a versatile, easy and rapid atmospheric monitor for benzene, toluene, ethylbenzene and xylenes determination in air. J Chromatogr A 1216(48):8549-8556

Fernández-Villarrenaga V, López-Mahía P, Muniategui-Lorenzo S, Prada-RodríGuez D, Fernández-Fernández E, Tomàs X (2004) $\mathrm{C} 1$ to $\mathrm{C} 9$ volatile organic compound measurements in urban air. Sci Total Environ 334-335:167-176

Fujita EM, Watson JG, Chow JC, Lu Z (1994) Validation of the chemical mass balance receptor model applied to hydrocarbon source apportionment in the Southern California air quality study. Environ Sci Technol 28(9):1633-1649

Girgis BS, Kader AA, Aly ANH (1997) Development of porosity in bone char during decolourization of sugar syrup. Adsorpt Sci Technol 15(4):277-287

Górecki T, Namieśnik J (2002) Passive sampling. TrAC Trends Anal Chem 21(4):276-291

Haagen-Smit AJ, Fox MM (1956) Ozone formation in photochemical oxidation of organic substance. Ind Eng Chem 48(9):1484-1487

Hoque RR, Khillare PS, Agarwal T, Shridhar V, Balachandran S (2008) Spatial and temporal variation of BTEX in the urban atmosphere of Delhi. India. Environ Sci Technol 392(1):30-40

Hsu DJ, Huang HL (2009) Concentrations of volatile organic compounds, carbon monoxide, carbon dioxide and particulate matter in buses on highways in Taiwan. Atmos Environ 43(36):5723-5730

IARC (2012) IARC monograph on the evaluation of carcinogenic risks to humans. http://monographs.iarc.fr/ENG/Classification/ index.php

Ip AWM, Barford JP, McKay G (2010a) A comparative study on the kinetics and mechanisms of removal of Reactive Black 5 by adsorption onto activated carbons and bone char. Chem Eng $\mathbf{J}$ 157(2-3):434-442

Ip AWM, Barford JP, Mckay G, Alvin WM (2010b) Biodegradation of Reactive Black 5 and bioregeneration in upflow fixed bed 
bioreactors packed with different adsorptions. J Chem Technol Biotechnol 85(5):658-667

Kaseva ME (2006) Optimization of regenerated bone char for fluoride removal in drinking water: a case study in Tanzania. J Water Health 4(1):139-147

Kawasaki N, Ogata F, Tominaga H, Yamaguchi I (2009) Removal of fluoride ion by bone char produced from animal biomass. J Oleo Sci 58(10):529-535

Khoder MI (2007) Ambient levels of volatile organic compounds in the atmosphere of Greater Cairo. Atmos Environ 41(3):554566

Kim SC (2002) The catalytic oxidation of aromatic hydrocarbons over supported metal oxide. J Hazard Mater B91:285-299

Kolasinski KW (2008) Surface science: foundations of catalysis and nanoscience, 2nd edn. Wiley, UK

Laowagul W, Garivait H, Limpaseni W, Yoshizumi K (2008) Ambient air concentrations of benzene, toluene, ethylbenzene and xylene in Bangkok, Thailand during April-August in 2007. Asian J Atmos Environ 2-1:14-25

Lee SC, Chiu MY, Ho KF, Zou SC, Wang X (2002) Volatile organic compounds (VOCs) in urban atmosphere of Hong Kong. Chemosphere 48(3):375-382

Leyva-Ramosa R, Rivera-Utrillab J, Medellin-Castilloa NA, Sanchez-Polob M (2010) Kinetic modeling of fluoride adsorption from aqueous solution onto bone char. Chem Eng J 158(3):458-467

Medellin-Castillo NA, Leyva-Ramos R, Padilla-Ortega E, Perez RO, Flores-Cano JV, Berber-Mendoza MS (2014) Adsorption capacity of bone char for removing fluoride from water solution. Role of hydroxyapatite content, adsorption mechanism and competing anions. J Ind Eng Chem 20(6):4014-4021

Mwaniki DL (1992) Fluoride sorption characteristics of different grades of bone charcoal based on batch tests. J Dent Res 71(6):1310-1315

$\mathrm{Na} \mathrm{K}$ (2006) Determination of VOC source signature of vehicle exhaust in a traffic tunnel. J Environ Manage 81(4):392-398

Na K, Kim YP, Moon I, Moon KC (2004) Chemical composition of major VOC emission sources in the Seoul atmosphere. Chemosphere 55(4):585-594

Odabasi M, Ongan O, Cetin E (2005) Quantitative analysis of volatile organic compounds (VOCs) in atmospheric particles. Atmos Environ 39(20):3763-3770

Ooi CY, Hamdi M, Ramesh S (2007) Properties of hydroxyapatite produced by annealing of bovine bone. Ceram Int 33(7):1171-1177

Parra MA, González L, Elustondo D, Garrigó J, Bermejo R, Santamaría JM (2006) Spatial and temporal trends of volatile organic compounds (VOC) in a rural area of northern Spain. Sci Total Environ 370(1):157-167

Parra MA, Elustondo D, Bermejo R, Santamaría JM (2008) Exposure to volatile organic compounds (VOC) in public buses of Pamplona, Northern Spain. Sci Total Environ 404(1):18-25

PCD (2009) Situation and management of air and noise pollution. (in Thai) http://www.pcd.go.th/public/Publications/print_report. cfm?task=air_noise 51
Pekey B, Y1lmaz H (2011) The use of passive sampling to monitor spatial trends of volatile organic compounds (VOCs) at an industrial city of Turkey. Microchem J 97(2):213-219

Pennequin-Cardinal A, Plaisance H, Locoge N, Ramalho O, Kirchner S, Galloo JC (2005) Performances of the Radiello ${ }^{\circledR}$ diffusive sampler for BTEX measurements: influence of environmental conditions and determination of modelled sampling rates. Atmos Environ 39(14):2535-2544

Perry R, Gee I (1995) Vehicle emissions in relation to fuel composition. Sci Total Environ 169(1-3):149-156

Rezaee A, Rangkooy H, Jonidi-Jafari A, Khavanin A (2013) Surface modification of bone char for removal of formaldehydefrom air. Appl Surf Sci 286:235-239

Rojas-Mayorga CK, Bonilla-Petriciolet A, Aguayo-Villarreal IA, Hernández-Montoya V, Moreno-Virgen MR, Tovar-Gómez R, Montes-Morán MA (2013) Optimization of pyrolysis conditions and adsorption properties of bone char for fluoride removal from water. J Anal Appl Pyrolysis 104:10-18

Rojas-Mayorga CK, Silvestre-Albero J, Aguayo-Villarreal IA, Mendoza-Castillo DI, Bonilla-Petriciolet A (2014) A new synthesis route for bone chars using $\mathrm{CO}_{2}$ atmosphere and their application as fluoride adsorbents. Microporous Mesoporous Mater 29:38-44

Rowe RK, Mukunoki T, Sangam HP (2005) BTEX diffusion and sorption for a geosynthetic clay liner at two temperatures. J Geotech Geoenviron Eng 131(10):1211-1221

Seethapathy S, Górecki T (2010) Polydimethylsiloxane-based permeation passive air sampler. Part II: effect of temperature and humidity on the calibration constants. J Chromatogr A 1217(50):7907-7913

Seethapathy S, Górecki T (2011) Polydimethylsiloxane-based permeation passive air sampler. Part I: calibration constants and their relation to retention indices of the analytes. J Chromatogr A 1218(1):143-155

Seethapathy S, Górecki T, Li X (2008) Passive sampling in environmental analysis. J Chromatogr A 1184(1-2):234-253

Sopajaree K, Chantara S, Koonaphapdeelert S, Thiengburanathum P, Preechanukul N (2011) The development of an emission inventory for Chiang Mai City under the clean air for smaller cities in the ASEAN region project. German International Cooperation (GIZ)

Suwanttiga P, Limpaseni W (2005) Seasonal source apportionment of volatile organic compounds in Bangkok ambient air. ScienceAsia 31:395-401

Thailand Meteorological Department (2012) www.tmd.go.th

Thammakhet C, Muneesawang V, Thavarungkul P, Kanatharana P (2006) Cost effective passive sampling device for volatile organic compounds monitoring. Atmos Environ 40(24):4589-4596

Thijesse TR, Van Oss RF, Lenschow P (1999) Determination of source contributions to ambient volatile organic compound concentrations in Berlin. J Air Waste Manage Assoc 49(12):1394-1404

Tolnai B, Hlavay J, Möller D, Prümke HJ, Becker H, Dostler M (2000) Combination of canister and solid adsorbent sampling 
techniques for determination of volatile organic hydrocarbons. Microchem J 67(1-3):163-169

Truc VTQ, Oanh NTK (2007) Roadside BTEX and other gaseous air pollutants in relation to emission sources. Atmos Environ 41(36):7685-7697

US EPA (2012) Technology transfer network air toxic website; Benzene. http://www3.epa.gov/airtoxics/hlthef/benzene.html
Zabiegała B, Namieśnik J, Przyk E, Przyjazny A (1999) Changes in concentration levels of selected VOCs in newly erected and remodelled buildings

in

Gdansk.

Chemosphere
39(12):2035-2046 